Abstracta Iranica Abstracta Iranica

Revue bibliographique pour le domaine irano-aryen

Volume 34-35-36 | 2017

Comptes rendus des publications de 2011-2013

\title{
Bruno Overlaet. Ardashir II or Shapur III? Reflections on the Identity of a King in the Smaller Grotto at Taq-i Bustan
}

\section{Barbara Kaim}

\section{(2) OpenEdition}

Journals

Édition électronique

URL : http://journals.openedition.org/abstractairanica/42317

DOI : 10.4000/abstractairanica.42317

ISSN : 1961-960X

Éditeur :

CNRS (UMR 7528 Mondes iraniens et indiens), Éditions de l'IFRI

Référence électronique

Barbara Kaim, "Bruno Overlaet. Ardashir II or Shapur III? Reflections on the Identity of a King in the Smaller Grotto at Taq-i Bustan », Abstracta Iranica [En ligne], Volume 34-35-36 | 2017, document 40, mis en ligne le 30 juillet 2017, consulté le 02 octobre 2020. URL : http://journals.openedition.org/ abstractairanica/42317; DOI : https://doi.org/10.4000/abstractairanica.42317

Ce document a été généré automatiquement le 2 octobre 2020.

Tous droits réservés 


\title{
Bruno Overlaet. Ardashir II or Shapur III? Reflections on the Identity of a King in the Smaller Grotto at Taq-i Bustan
}

\author{
Barbara Kaim
}

\section{RÉFÉRENCE}

Bruno Overlaet. « Ardashir II or Shapur III? Reflections on the Identity of a King in the Smaller Grotto at Taq-i Bustan ». IA, 46, 2011, p. 235-250.

1 Deux personnages debout sculptés sur la paroi du fond du petit iwān de Taq-i Bustan, près de Kermanshah et accompagnés d'une inscription pehlevie ont été identifiés comme étant Shapur II (309-379 A.D.) et son fils Shapur III (383-388 A.D.). Il était généralement admis que le relief a été ordonné par Shapur III pour démontrer la continuité de la lignée royale après le règne éphémère de son oncle Ardashir II placé sur le trône par les puissants de l'empire à la mort de Shapur II. Cependant, comme le note l'A., les détails des couronnes et la conception du relief indiquent la possibilité que la figure identifiée comme Shapur III soit en fait celle d'Ardashir II (379-383 A.D.), le successeur immédiat de Shapur II. L'A. suggère que les inscriptions mentionnant les noms de Shapur II et de Shapur III ont été ajoutées lorsque ce dernier est arrivé au pouvoir. 


\section{AUTEURS}

BARBARA KAIM

Université de Varsovie 